\title{
МОЛЕКУЛЯРНО-ГЕНЕТИЧЕСКОЕ ОПРЕДЕЛЕНИЕ ФИТОПАТОГЕННОГО ПОРАЖЕНИЯ ПЛОДОВ ТОМАТА НА РАННИХ СТАДИЯХ
}

\author{
Белоусова Галина, Шубина Виктория \\ Институт генетики, физиологии и защиты растений, Кишинэу, Республика Молдова \\ e-mail:belousovagalina@mail.ru
}

Рост вредоносных микологических заболеваний томата тесно связан с ухудшением экологической обстановки, значительным перемещением сельскохозяйственных культур, интенсивным использованием химических удобрений и пестицидов и другими факторами. Около 85\% всех болезней растений вызываются грибковыми или грибоподобными организмами. Интенсивное использование химических удобрений и пестицидов в борьбе с микозами растений являются высокоэффективными, но дорогостоящими средствами. Поэтому поиск новых агентов, способных подавлять рост патогенных микроорганизмов и одновременно способствовать росту и урожайности растений является актуальной задачей. В настоящее время возрос интерес к экологически чистым биопрепаратам. Альтернативой химическим удобрениям и пестицидам является использование микроорганизмов.

Нами изучено влияние бактериальной суспензии Bacillus subtilis CNMN BB-09 в концентрации 0,5\% $u$ химического препарата Cupromax на фитопатогенное поражение плодов томата сорта Томиш в полевом опыте. Контролем служил вариант без обработки. Диагностику плодов на присутствие фитопатогенов проводили молекулярными методами, что способствовало точности и достоверности исследований. Для выявления фитопатогенов с растений были отобраны здоровые зеленные плоды томата на стадии первой кисти. Плоды были промыты детергентом и многократно дистиллированной водой для снятия поверхостной инфекции. Из них выделена ДНК с использованием SDS метода (метод выделения ДНК с помощью додецилсульфат натрия).

Проведено тестирование ДНК на присутствие грибных фитопатогенов Alternaria spp., Fusarium spp., и Myrothecium roridum с помощью метода nested PCR. Для каждого патогена использовали специфичные праймеры. Патогены Alternaria spp. определяли, используя праймеры к гену RNA polymerase II second largest subunit (rpb 2), Fusarium spp. определяли с помощью праймеров из последовательности гена final elongation factor TEF1 нуклеотидного банка NCBI. Для M. roridum использовали праймеры из последовательности ITS small subunit ribosomal RNA gene. Результаты оценивали с помощью электрофоретического разделения ампликонов в $1 \%$ агарозном геле с последующим окрашиванием бромистым этидием.

Для варианта с биологической обработкой бактериальной суспензией Bacillus subtilis CNMN BB-09 фumonamozены Alternaria spp. и Fusarium spp. не были идентифицированы. При химической обработке Alternaria spp. выявлена в 11\% образцов. Fusarium spp. присутствовал в $11 \%$ образцов. В контрольном варианте Fusarium spp. не выявлен ни в одном образце, а патоген Alternaria spp. присутствовал в 11\% образцов. Во всех трёх случаях патоген M. roridum не был выявлен ни в одном из проанализированных образцов.

Проведённые молекулярно-генетические исследования по выявлению фитопатогенов в полевом эксперименте показали, что биологическая обработка полевого опыта бактериальной суспензией Bacillus subtilis CNMN BB-09 в концентрации 0,5\% на ранних этапах способствует защите томатных растений от тестированных фитопатогенов Alternaria spp. и Fusarium spp., M. roridum. Биопрепарат на основе Bacillus subtilis CNMN BB-09 может быть использован для защиты растений. 